Fikrah: Jurnal Ilmu Aqidah dan Studi Keagamaan issn 2354-6174 eissn 2476-9649

Tersedia online di: journal.iainkudus.ac.id/index.php/fikrah

Volume 8 Nomor $12020,(19-24)$

DOI: $10.21043 /$ fikrah.v8i1. 7214

\title{
Jihad Digital: Pembingkaian Narasi Kontra Radikalisasi NU Online di Dunia Maya
}

\author{
Sefriyono \\ Universitas Islam Negeri Imam Bonjol, Padang, Indonesia \\ sefriyono@uinib.ac.id
}

\begin{abstract}
Abstrak
Perkembangan digitalisasi telah menggeser pola-pola pelembagaan nilai dari konvensional ke dunia maya, termasuk pelembagaan nilai-nilai radikal melalui situs-situsnya yang juga berkembang seiring dengan perkembangan digitalisasi. Radikalisasi di dunia maya menghendaki adanya situs-situs tandingan yang berkomitmen pada moderasi beragama. Satu dari situs-situs ini adalah NU Online. Riset ini menggunakan metode penelitian kualitatif teks dengan framing sebagai teknik analisis data. NU Online mendiagnosis, narasi-narasi radikalisasi dan intoleran di dunia maya merupakan sumber kegaduhan ideologi bangsa dan disharmoni hubungan antar agama. Dalam strategi prognosisnya, NU Online mengembangkan narasi-narasi seperti Islam sangat sesuai dengan Pancasila. Sementara dalam strategi motivasionalnya, NU Online mengajak semua elemen bangsa untuk mempertahankan integrasi bangsa dengan penerbitkan headline seperti "empat alasan penolakan khilafah". Framing kontra radikalisasi ini berbeda dengan yang dilakukan oleh Panjimas.com sebagai representasi situs radikal.
\end{abstract}

Kata kunci: diagnosis, motivasional, narasi, prognosis, radikalisasi 


\begin{abstract}
The development of digitalization has shifted the institutionalization values patterns from conventional to cyberspace, it is containing radical values through the website which also developed along with the development of digitalization. Radicalization in cyberspace requires the counter-sites which committed to religious moderation. NU Online is one of this counter-site. This study uses qualitative methods with data analysis framing techniques. NU Online distinguishes the radicalization and intolerance narratives in cyberspace is a source of the uproar of the national ideology and disharmony in the interfaith relations. In its prognosis strategy, NU Online develops the narratives such as Islam is very compatible with Pancasila. While in its motivational strategy, NU Online invites all elements of the nation to maintain the integration of the nation by publishing the headline such as "four reasons for rejecting the Khilafah". This counter-radicalization framing is different from that carried out by panjimas.com as a representation of the radical site.
\end{abstract}

Keywords: motivational, narrative, prognosis, radicalization diagnose

\title{
Pendahuluan
}

Istilah jihad banyak diperbincangkan setelah pengeboman Menara Kembar World Trade Center 11 September 2001. Peristiwa yang dikenal dengan Peristiwa 9/11 ini telah mempopulerkan nama al-Qaeda ke seluruh dunia, sebagai kelompok radikal dalam Islam dengan sel-selnya, karena dianggap bertanggungjawab terhadap peristiwa tersebut (Said Ali, 2002, hal. i). Peristiwa ini juga menandai adanya perluasan makna dan objek jihad. Jihad tidak hanya ditujukan pada Amerika dan Barat, serta tidak mesti dilakukan secara berkelompok di bawah kepemimpinan seseorang yang memiliki otoritas, melainkan juga bisa ditujukan terhadap muslim sendiri yang menurut pemahaman mereka belum lagi berislam secara kaffah dan jihad juga merupakan tanggung jawab individual dari yang semula merupakan tanggung jawab komunal. Karenanya sasaran jihad tidak hanya Amerika dan Barat sebagai perwujudan dari simbol kekristenan, keyahudian dan penjajah. Tetapi juga muslim yang tidak tunduk pada sistem Islam seperti Indonesia meski berpenduduk mayoritas muslim. Perubahan makna dan sasaran jihad ini terlihat ketika Osama bin Ladin mendeklarasikan program jihad global di mana jihad mesti dilakukan oleh setiap muslim di seluruh dunia, yakni membunuh orang-orang Amerika dan aliansi-aliansinya, baik sipil maupun militer. Tugas jihad ini tidak lagi merupakan tugas komunal, melainkan tugas individual setiap muslim di negara apa pun dan di mana pun mungkin dilakukan (JeanPierre Filliu, 2014, hal. 203).

Perkembangan baru tentang jihad adalah ada perubahan pelaksanaan jihad dari yang semula dilakukan secara konvensional dalam bentuk 
konfrontasi fisik, menjadi dilakukan dengan menggunakan media digital, salah satunya melalui media online. Keampuhan media ini diakui oleh tokoh-tokoh kelompok radikal dalam Islam seperti Osama dan Ayman al-Zawahiri. Duaduanya adalah tokoh al-Qaeda. Bagi Osama, perang media saat ini merupakan metode yang sangat ampuh dalam jihad. Rasionya $90 \%$ dari total persiapan pertempuran dilakukan melalui media. Pernyataan ini diperkuat oleh Ayman al-Zawahiri sebagai tangan kanannya Osama. Bagi Ayman, lebih dari separo peperangan atau jihad terjadi dalam bentuk pertempuran di media. Era sekarang adalah perlombaan untuk hati dan pikiran ummah melalui media. Jihad media dilakukan karena adanya kesadaran di kalangan jihadis tentang lebarnya jarak antara gerakan jihad dan masyarakat awam, terutama terkait dengan pemahaman akan makna jihad. Karenanya jihadis harus memperlebar fokus jihadnya pada jihad media sebagai kendaraan utama untuk menghindari kegagalan jihad ideologi (Akil N. Awan, 2015, hal. 10). Jihad media dalam pandangan jihadis tentu lebih ditekankan pada produksi dan diseminasi konten dan narasi radikal melalui media daripada konten dan narasi moderat dan inklusif. Jihad media dalam konteks ini lebih dimaknai sebagai radikalisasi melalui media online yang ditujukan pada konsumer media dimaksud dalam rangka penyebaran paham-paham radikal dan perekrutan untuk menjadi bagian dari kelompok radikal.

Radikalisasi di dunia maya tidak kalah hebatnya dengan yang terjadi dunia nyata sehingga membutuhkan jihad tandingan dalam bentuk usahausaha memproduksi dan mendiseminasi fitur-fitur moderat. Jihad tandingan ini harus dilakukan mengingat pesatnya pertumbuhan media online yang menyajikan konten dan narasi radikal. Dalam rentang tahun 2010 sampai sekarang pemerintah melalui Kementerian Komunikasi dan Informatika telah melakukan pemblokiran terhadap 814.594 situs radikal (Editor, 2018g). Radikalisasi di dunia maya telah menggoyahkan sendi-sendi kehidupan bernegara dan beragama. Penyebaran konten dan narasi anti Pancasila, anti Negara Kesatuan Republik Indonesia (NKRI), kebhinekaan dan ekslusivisme telah melahirkan kelompok-kelompok anti negara dan intoleran. Adanya 19, 4 \% Pegawai Negeri Sipil (PNS) yang anti Pancasila merupakan bentuk dari terkikisnya ideologi negara oleh warga negaranya (Editor, 2018d).

Jihad media yang dilakukan oleh jihadis, termasuk jihadis lokal dalam bentuk manfaatkan media online sebagai alat produksi dan diseminasi konten dan narasi radikalisme mengharuskan adanya media tandingan yang mengusung konten dan narasi moderasi beragama yang mengembangkan 
nilai-nilai moderat dan inklusif. Ketika jihadis memanfaatkan media online untuk menyebarkan nilai-nilai anti demokrasi, Pancasila, NKRI, dan kebhinekaan, mengharuskan adanya media tandingan yang mengusung nilainilai sebaliknya dalam narasi-narasi beritanya. Jihad dalam makna yang luas berarti bersungguh-sungguh dan bekerja keras dalam melakukan kebaikan. Jihad dapat dilakukan dengan berbagai cara, tidak hanya dengan mengangkat senjata. Era digital yang ditandai dengan kemajuan teknologi informasi yang tidak jarang menghadirkan ujaran kebencian dan hoaks merupakan tantangan bagi anak bangsa yang menghendaki adanya usaha-usaha yang sungguhsungguh untuk mengatasinya. Usaha ini bisa disebut dengan jihad demi kebaikan. Jika ini dibiarkan akan menimbulkan masalah yang serius bagi kehidupan berbangsa dan bernegara. Melakukan kontra narasi radikalisasi dengan memproduksi dan mendiseminasi literasi sehat bagi keutuhan NKRI misalnya juga merupakan bagian dari tindakan jihad. Melakukan amar ma'ruf nahi mungkar dalam bentuk melindungi negara dari berbagai ancaman perpecahan, terutama intoleransi di dunia maya juga merupakan bagian dari jihad di dunia digital. Karena Indonesia yang terbangun dari keragaman suku dan agama akan digerogoti oleh intoleransi manakala menerapkan pola berislam garis keras. Terkait dengan hal ini, melakukan amar ma'ruf dalam bentuk berperan aktif menyebarkan nilai-nilai Islam rahmatan lil alamin di dunia maya juga merupakan bagian dari tindakan jihad (editor, 2019). Salah satu media online yang berkomitmen dengan moderasi Islam dalam bentuk berusaha mendialogkan keislaman dan kebangsaan adalah NU Online.

Tulisan ini berusaha menganalisis bagaimana NU Oline membingkai narasi-narasi kontra radikalisasi di dunia maya, terutama terkait dengan hubungan keislaman dan kebangsaan. Kehadiran Islam bagi NU Online tidak bertentangan dengan nilai-nilai kebangsaan. Akan tetapi menguatkan nilainilai kebangsaan itu sendiri. Begitu juga dengan nilai-nilai toleransi, kehadiran Islam merupakan rahmat bagi alam. Bagaimana NU Online melakukan framing dalam bentuk diagnosis, prognosis dan motivasional bagi usaha-usaha pencegahan radikalisasi di dunia maya merupakan masalah utama yang digali dalam tulisan ini. Produksi dan diseminasi narasi moderat dan inklusif sebagai bagian dari strategi kontra narasi radikalisasi yang dilakukan oleh NU Online akan dianalisis menggunakan tiga strategi framing di atas. Situs Panjimas.com digunakan sebagai pembanding narasi NU Online. Kerena situs ini merupakan 1 dari 22 situs yang digolongkan sebagai situs radikal (Editor, 2015a). 


\section{Digitalisasi dan Pewarisan Nilai}

Digitalisasi sebagai konsekuensi kemajuan teknologi informasi telah mengalihkan proses pelembagaan nilai dari konvensional ke dunia maya. Jika sebelumnya pelembagaan nilai berlangsung melalui interaksi sosial konvensional seperti melalui relasi guru-murid dalam proses pembelajaran baik formal maupun informal, melalui guru agama di tempat-tempat ibadah, melalui keluarga sebagai media sosialisasi primer, sekarang berlangsung secara digital melalui media online seperti Facebook, Twitter, WhatsApp, Instagram dan media online lain seperti Ditik.com, Kompas.com, NU Online, Islampos.com, Tempo.co, Panjimas.com dan Merdeka.com. Pelembagaan nilai berlangsung dengan mudah dengan menggunakan handphone yang menyediakan layanan android.

Di Indonesia masyarakat online, masyarakat internet, atau masyarakat digital sebagai bagian dari digitalisasi selalu mengalami peningkatan dari tahun ke tahun. Pada tahun 2015, masyarakat online (masyarakat pengguna media online) berjumlah 93,4 juta dari 270 juta penduduk Indonesia. Pada tahun ini ada sekitar $35 \%$ pengguna media online dari total penduduk Indonesia. Angka ini meningkat dari dua tahun sebelum, yakni 72, 7 tahun 2013 dan 83, 6 juta pada tahun 2014. Berdasarkan angka-angka ini, ada sekitar $20 \%$ pertumbuhan pengguna media online di Indonesia setiap tahunnya (Kuswarno, 2015, hal. 49). Pada tahun 2015, APPJI meramalkan dengan total penduduk Indonesia 300 juta 2019, ada 150 juta pengguna internet. Ramalan ini dibuktikan melalui riset yang dilakukan oleh "Wearesosial Hootsuite" yang dirilis pada tahun 2019 bahwa pengguna media sosial di Indonesia ada sekitar 150 juga atau sekitar $56 \%$. Hal tersebut meningkat $20 \%$ dari tahun sebelumnya, yakni 130 juta atau $48 \%$ dari total penduduk Indonesia (Editor, 2019a).

Kehadiran media online sebagai produk budaya berperan memudahkan kehidupan manusia. Bagi pencinta kuliner misalnya dengan mudah mengakses berbagai situs kuliner dengan segala variannya, baik tradisional maupun modern lengkap dengan teknik pembuatannya. Bagi pemburu ilmu, dengan menyentuh fitur-fitur smartphone, mereka akan menemukan varian keilmuan sesuai dengan minat yang mereka miliki. Paham keagamaan dengan segala varian, mulai dari yang moderat sampai dengan yang radikal juga bisa dengan mudah ditemukan melalui benda ajaib ini. Dalam konteks pelembagaan nilai, media online merupakan salah satu media sosialisasi. (Setiadi \& Kolip, 2010, 
hal. 181). Media online bisa membentuk pola pikir dan rasa seseorang sehingga melahirkan sikap sosial. Media online juga bisa melahirkan jati diri peminatnya. Karenanya media online dapat membentuk kepribadian penggunanya (Soekanto, 2017, hal. 159-161).

Menjadi agamawan yang toleran dan radikal bisa dibentuk melalui media online. Termasuk menjadi warga negara yang berkomitmen dengan nilai-nilai kebangsaan dan anti negara juga bisa terbentuk melalui media sosial. Internet telah mengubah pola konsumsi generasi milenial terhadap informasi agama. Mereka yang dulunya mendapatkan ajaran agama melalui media cetak, seperti buku, majalah dan jurnal, serta pengajian-pengajian dari ustadz atau mubaligh, sekarang beralih ke media konvergensi yang lebih instan dan kerap menyajikan konten dan narasi keagamaan secara parsial. Internet menjadi alat pencarian informasi agama secara sporadis. Fenomena ini sejatinya penanda bahwa ada pola interaksi sosial dan pembicaraan agama lewat kanal-kanal baru, yang menyampaikan pesan, propaganda, serta penyebaran paham-paham radikal dan ekstrim dalam beragama. Ruang baru tersebut bukan sekedar alat, melain keniscayaan bagi generasi milenial (Editor, 2018e). Internet sebagai bagian dari proses digitalisasi masyarakat juga merupakan media yang dipergunakan untuk mendapatkan pengetahuan dan pemahaman tentang Islam bagi penggunanya. Karenanya sikap beragama umat Islam sangat bergantung pada pola beragama seperti apa yang mereka konsumsi. Ketika mereka mengonsumsi paham keagamaan radikal dan ekslusif, maka sikap radikal dan ekslusif akan menjadi kepribadian mereka. Begitu pula sebaliknya, ketika mengonsumsi pola beragama yang moderat dan inklusif, maka muslim dimaksud akan menjadi moderat dan inklusif (Amelia Fauzia at.al, 2011, hal. 36).

Perkembangan situs-situs radikal di media online sudah pada tataran mengkhawatirkan. Dalam rentang waktu 2009-2019, Kementerian Komunikasi dan Informatika telah melakukan pemblokiran terhadap 11.000 konten yang memuat radikalisme dan terorisme (Editor, 2019c). Radikalisme telah menggoyahkan nilai-nilai berbangsa dan beragama. Sikap anti Pancasila dan intoleransi telah menyusup pada berbagai profesi dan telah terjadi di tempat-tempat ibadah. Sikap radikal terlihat dari hasil-hasil riset berikut: pertama, 19, 4\% PNS tidak setuju dengan ideologi Pancasila. Hal ini terlihat dari hasil penelitian yang dilakukan oleh Alvara Research pada tanggal 10 September sampai 5 Oktober 2017 di enam kota--Bandung, Semarang, Surabaya, Medan, dan Makasar, responden 1.200 PNS, swasta, profesional dan 
BUMN dengan rentang usia 25-40 tahun (Editor, 2018f); kedua, lembaga riset yang sama juga menyebutkan, 40, 9 \% generasi milenial Muslim Indonesia berorientasi nasionalis-religius, 35,8 nasionalis, 23,3 berorientasi religius. Riset ini dilakukan pada 1.097 responden di 33 provinsi (Editor, 2018a); ketiga, dari 100 masjid yang dimiliki gabungan kementerian, lembaga, dan BUMN, 40 di antaranya terpapar paham radikal, 7 kategori rendah, 17 kategori sedang, 17 kategori berat (Editor, 2018b); keempat, 7 Perguruan Tinggi Negeri (PTN) terpapar radikalisme yaitu UI, UNDIP, AIRLANGGA, BRAWIJAYA, ITB, IPB, dan ITS (Editor, 2018c).

Menyikapi situs-situ radikal membutuhkan dua bentuk kecerdasan, yakni kecerdasan pada konsumer media dan kecerdasan pada produsen media. Konsumer media harus menjadi pribadi yang cerdas, sehingga media sosial tersebut konstruktif bagi pembentukan kepribadian mereka. Sebaliknya media sosial akan destruktif bagi penggunanya manakala konsumer media sosial tidak cerdas dalam literasi media. Karena media sosial tidak hanya menghadirkan konten-konten moderat tatapi juga radikal. Di samping cerdas literasi sebagai modal personal dalam menyikapi konten dan narasi suguhan media online, juga diperlukan situs-situs cerdas yang berkomitmen menghadirkan konten dan narasi sehat bagi konsumennya. Pusat Studi Budaya dan Perubahan Sosial (PSBPS) Universitas Muhammadiyah Surakarta (UMS) bersama Pusat Pengkajian Islam dan Masyarakat (PPIM) UIN Jakarta menemukan situs-situs media online yang tetap berkomitmen menyuguhkan konten dan narasi moderat yang menekankan pentingnya integrasi umat, pesan yang menyejukkan, dan membawa pesan Islam rahmat bagi semua. Di antara situs milik organisasi Islam arus utama yang memiliki komitmen terhadap moderasi beragama ini adalah NU Online dan Suara Muhammadiyah (Editor, 2018e). Artikel ini lebih banyak mengeksplorasi bagaimana NU Online melakukan framing konten dan narasi moderasi beragama dalam kaitannya dengan kebangsaan dan keragaman.

NU Online dengan alamat situs www.nu.or.id. telah ada sejak 2002 dan merupakan salah satu media online milik organisasi Islam arus utama terbesar di Indonesia, yakni Nahdlatul Ulama (NU). Media ini merupakan alat pelembagaan kultur keislaman NU, terutama kultur moderasi Islam dalam hubungannya dengan kehidupan berbangsa dan beragama. NU Online yang lahir tahun 2002 digagas oleh KH. Ahmad Hasyim Muzadi, Masduki Baidlawi, Taufik R Abdullah, Saiful Bahri Anshori dan Mu'im DZ. Sedangkan yang menjadi Pimpinan Redaksi adalah Mun'im DZ. Pada tahun 2005 situs ini 
mendapatkan penghargaan sebagai situs Indonesia terbaik dari Majalah Komputer Aktif Kategori Sosial dan Kemasyarakatan. Sejak tahun 2006, NU Online menurunkan tulisan dalam tiga bahasa: Indonesia, Arab, dan Inggris. Situs inilah yang menjadi sarana penyebaran informasi paling efektif berkenaan dengan berita-berita perkembangan NU ke seluruh dunia (Abdul Muchith Muzadi, 2010, hal. 12).

\section{Framing: Pembingkaian Teoritik Kontra Radikalisasi}

Framing lazim digunakan pada penelitian-penelitian yang terkait dengan media--bagaimana media, termasuk media online seperti koran online melalui wartawan-wartawannya memaknai realitas atau peristiwa. Framing menjadikan pembentukan pesan dari teks sebagai pusat perhatiannya. Lebih spesifik framing menekankan perhatiannya pada bagaimana pesan dan peristiwa dimaknai oleh media. Kemudian bagaimana wartawan memaknai peristiwa dan menyajikannya kepada konsumen berita dimaksud. Karena sangat terkait dengan makna, penggunaan framing sebagai alat analisis yang terfokus pada usaha-usaha untuk memahami, mengerti (verstehen) dan menafsirkan makna dari suatu teks dalam bentuk pembingkaian isu yang dilakukan oleh media dimaksud. Berdasarkan hal ini, pembingkaian isu yang dilakukan satu media akan berbeda dengan yang dilakukan oleh media lain. Dalam memaknai konflik Palestina misalnya, antara Republika dan Kompas memiliki perbedaan pemaknaan. Dalam pemaknaan Republika, solusi konflik Timur Tengah bisa dicapai dengan pemberian kemerdekaan bagi Palestina. Karena rangkaian peristiwa konflik yang terjadi di Timur Tengah dimaknai dengan konsekuensi dari kebiadaban Israel. Pemaknaan ini berbeda dengan yang dilakukan oleh Kompas - kekerasan tidak akan menyelesaikan konflik di Timur Tengah. Solusi yang terbaik bagi hal ini adalah penguatan gerakan perdamaian. Kekerasan tidak akan menyelesaikan permasalahan, malah sebaliknya akan menambah amunisi konflik sehingga sulit dihentikan (Eriyanto, 2012, hal. 10).

Framing dalam telaah terhadap peristiwa juga menekankan perhatiannya pada bagaimana aktor yang dalam hal ini pengelola media mengemas, mengkonstruksi pesan-pesan tersebut sehingga menarik dikonsumsi oleh konsumen. Karenanya tingkat konsumsi media sangat ditentukan oleh sejauh mana pengelola media mampu menkonstruksi dan mengemas peristiwa menjadi menarik dan layak untuk disajikan (Jamil, n.d.). Framing yang dilakukan media terlihat dari bagaimana media dimaksud 
mengemas beritanya. Di antara cara yang dilakukan adalah meletakannya di judul berita (heading), pada anak judul, pada foto, keterangan foto, atau pada kalimat-kalimat pembuka berita (Ade Armando at.al, 2011, hal. 27). Terkait dengan hal ini, peran gagasan sangat penting. Bagaimana makna diproduksi, diartikulasikan dan disajikan merupakan daya tarik tersendiri sebuah berita oleh konsumennya. Dalam konteks gerakan sosial pun keberhasilan sebuah gerakan sangat bergantung pada bagaimana gagasan dikemas sehingga menjadi daya tarik dalam memobilisasi gerakan (Wiktorowicz, 2007, hal. 15).

Ada tiga fungsi utama pembingkaian terhadap peristiwa dalam media online, yakni: pertama, bagaimana media mendiagnosis sebuah berita atau opini atau gagasan sehingga penting untuk diberitakan. Seberapa dampak negatif yang ditimbulkan, jika berita, gagasan atau opini tidak diberitakan. Terkait dengan pencegahan radikalisme, diagnosis lebih menekan kajiannya pada bahaya terhadap negara dan agama jika konten atau narasi radikal, intoleran dan hoaks diproduksi dan didiseminasi secara masif. Konten dan narasi radikal, intoleran dan hoaks bisa menggoyahkan kesetiaan warga negara terhadap ideologi negara dan juga melahirkan sikap-sikap beragama yang intoleran. Diagnosis yang ditelaah dalam tulisan ini adalah diagnosis yang dilakukan oleh NU Online terhadap konten-konten atau narasi-narasi radikalisasi dan hoaks yang diproduksi dan diseminasi oleh situs-situs radikal yang berbahaya bagi kehidupan berbangsa dan beragama seperti anti Pancasila dan intoleran. Sebagai perbandingan tulisan ini juga menelaah narasi-narasi yang didiagnosis oleh Panjimas.com. Karena media online ini tidak dikategorikan sebagai media online arus utama berbasis agama yang berkomitmen menyuarakan moderasi beragama sebagaimana halnya NU Online. Karenanya framing dalam diagnosisnya menekankan kajian pada tingkat kesalahan sebuah peristiwa, opini atau gagasan yang diproduksi, terutama di media online.

Kedua, kalau diagnosis lebih banyak menekankan telaahannya pada tingkat kesalahan, prognosis lebih banyak menelaah strategi yang digunakan media untuk menyelesaikan masalah atau kesalahan hasil diagnosis. Bagaimana media memprognosis sebuah berita, opini atau gagasan sehingga diagnosis yang dibuat terjawab merupakan tugas prognosis. Prognosis lebih banyak terkait dengan strategi dan taktik yang memberikan solusi terhadap persoalan yang didiagnosis. Ketiga, bagaimana media mampu menyajikan berita, opini atau gagasan sehingga menarik bagi konsumen media online dimaksud. Terkait dengan pencegahan radikalisme, ajakan untuk cerdas dalam 
mengonsumsi media atau yang lazim juga disebut dengan cerdas literasi merupakan bentuk dari pembingkaian strategi motivasional. Kata-kata kunci seperti radikal, intoleran dan hoaks perusak agama dan negara merupakan bentuk strategi pembingkaian ini (Benford et al., 2012, hal. 115-118).

\section{Metode}

Riset ini menggunakan metode penelitian kualitatif berbasis teks. Dalam konteks ini, penulis menjadikan teks sebagai sumber data. Teks berupa data tertulis seperti tulisan di media baik cetak maupun elektronik, surat menyurat, kebijakan pemerintah, notulen rapat dan lainnya (Afrizal, 2014, hal. 18). Dalam perkembangannya metode penelitian kualitatif setidaknya menjadikan empat tipe informasi sebagai sumber datanya, yakni: pengamatan, wawancara, dokumen dan audiovisual. Salah satu bentuk data audiovisual yang menjadi sumber data penelitian kualitatif adalah data yang bersumber dari sumbersumber internet seperti halaman utama website (John W. Creswell, 2015, hal. 219-222). Teks yang dijadikan sumber data dalam riset ini adalah NU Online dan Panjimas.com. NU Online merupakan satu dari media online yang berkomitmen dengan moderasi beragama. Sementara Panjimas.com dijadikan sebagai pembanding narasi kontra radikalisasi NU Online, karena media online ini merupakan representasi dari media radikal. Sementara teknik analisis data yang digunakan dalam penelitian ini adalah analisis framing Robert D. Benford dan David Snow yang meliputi; diagonis, prognosis dan motivasional (Benford et al., 2012).

\section{NU Online: Strategi Framing Kontra Radikalisasi}

Sebagai bagian dari payung besar Nahdlatul Ulama, NU Online berperan sebagai media pelembagaan nilai-nilai ke-NU-an. Karenanya tidak salah kalau ada hasil riset yang menempatkan media online Islam arus utama ini sebagai media yang berkomitmen memproduksi dan mendiseminasi narasi-narasi yang menekankan pentingnya integrasi umat, perlunya pesan yang menyejukkan dan menampilkan Islam yang menjadi rahmat bagi alam dan kemanusiaan. Berdasarkan pertimbangan ini, PSBPS Universitas Muhammadiyah Surakarta bersama PPIM Universitas Islam Negari Jakarta menyandingkan NU Online dan Suara Muhammadiyah sebagai media penyuara agama yang ramah (Editor, 2018e).

Suara moderat dan tolerannya NU Online tidak bisa dilepaskan dari payungnya yang memang sangat berkomitmen dengan pola-pola 
keberagamaan moderat dan anti radikalisme, baik dalam konteks beragama maupun bernegara. Kehadiran NU pada tanggal 31 Januari 1926 bukan tanpa alasan. Hadirnya NU membawa misi moderasi beragama, baik dalam konteks beragama maupun berbangsa dan bernegara. Ketika Syarif Husain, Raja Hijas (Makkah) pada tahun 1924 yang berpaham Sunni ditaklukkan oleh Abdul Aziz bin Saud yang beraliran Wahhabi. Wahhabisme melarang semua bentuk amaliah keagamaan ala kaum Sunni, dan akan menggantinya dengan model Wahhabi. Hal lebih lanjut yang terlihat dari sikap beragama seperti ini adalah pengamalan agama dengan sistem bermazhab, tawasul, ziarah kubur, Maulid Nabi, dan lain sebagainya akan segera dilarang. Lebih dari itu, dalam konteks politik, Raja Ibnu Saud juga ingin melebarkan pengaruh Wahhabi melalui kekuasaannya ke seluruh dunia Islam. Dengan dalih demi kejayaan Islam, dia berencana meneruskan kekhalifahan Islam yang terputus di Turki pasca runtuhnya Daulah Utsmaniyah. Untuk itu dia berencana menggelar Muktamar Khilafah di Kota Suci Makkah, sebagai penerus Khilfah yang putus itu. Seluruh negara Islam diundang untuk menghadiri muktamar tersebut, termasuk Indonesia. Semula yang direncanakan hadir salah satunya adalah K.H. Adul Wahab Hasbullah, karena pertarungan politik, namanya dicoret sebagai utusan Indonesia. Dua peristiwa di atas menjadi daya dorong yang kuat bagi lahirnya keorganisasian Nahdlatul Ulama. Meski pembaharuan menjadi kemestian, tetapi tidak mesti anti mazhab. Pembaharuan juga tidak mengharuskan orang melecehkan, merendahkan, dan menganggap bodoh ulama yang menolaknya. Pembaruan juga tidak mesti meninggalkan khazanah keilmuan yang sudah ada dan masih relevan (Abdul Muchith Muzadi, 2010).

Sikap moderat NU yang menjadi basis ideologi NU Online juga terlihat dari pola dakwah yang mereka usung. Pola dakwah NU yang juga merupakan pola dakwah Islam Nusantara adalah pola dakwah yang menunjukkan sikap anti kekerasan. Para pendakwah membawa Islam ke Nusantara tanpa disertai dengan kekerasan. Untuk tujuan apa pun, atas nama apa dan siapa pun, serta kepada siapa pun, bahkan untuk kepentingan agama Allah pun, cara-cara kekerasan harus dihindari. Karena jihad bagi kalangan NU, pada hakikatnya bertujuan untuk menghidupkan orang dan mengangkatkan martabat kemanusiaan (Umar, 2019, hal. 114). Tidak hanya moderat dalam beragama yang diperlihatkan dengan sikap-sikap inklusif dan toleran, NU sangat menolak Islam politik dalam artian pendirian negara Islam. Di samping terlihat dari penolakan terhadap muktamar Khilafah yang digagas oleh Ibnu Saud 
sebagaimana dijelaskan sebelumnya, pada skala nasional, NU sangat menolak ide-ide gerakan penegakan Khilafah Islamiyah.

Ketika alotnya diskusi terkait relasi Islam dan negara yang melahirkan dua kutub yang berseberangan. Satu sisi bersepakat menempatkan Islam sebagai agama dan negara; sedangkan di sisi lain memisahkan Islam dengan negara secara tegas. Di tengah polarisasi antara negara Islam dan tidak, maka pada Muktamar NU Banjar Masin Kalimantan Selatan tahun 1936, diputuskan konsep "darul Islam" - sebuah negara yang selamanya harus menjamin masyarakat Muslim menjalankan ajaran Islam. Begitu juga bagi pemeluk agama lain. Bagi KH. Bagi Said Aqil Siroj, secara teori keputusan Muktamar NU itu menyuguhkan model negara, yakni "darussalam was shuluh" (negara berdasarkan perdamaian). Konsep tersebut melengkapi teori sebelumnya, "darul Islam" (negara Islam), "darul harb" (negara non-muslim) yang berkembang di kalangan umat Islam sejak abad pertengahan hijrah. KH. Yasin Asymuni menambahkan bahwa maksud NU tentang konsep baru Islam yang lebih populer dengan istilah "darussalam" tersebut menempatkan negara sebagai hasil dari kesepakatan semua anak bangsa. Maka Indonesia pun bukan "daulah Islamiyah" (negara berdasarkan Islam) namun negara milik bersama. Konsekuensinya setiap warga negara mempunyai hak dan kewajiban yang sama dan kedudukan yang sama di mata hukum (Fatoni, 2017, hal. 97-99).

Nilai-nilai moderat Islam yang diusung oleh kapal besar NU ini, sudah tentu juga diejawantahkan oleh para awak-awaknya. Salah satu awak tersebut adalah NU Online. Narasi-narasi moderat, inklusif, toleran terutama terkait dengan relasi agama dengan negara merupakan pengejawantahan dari nilainilai ke-NU-an yang memang akomodatif dengan negara. Begitu juga nilainilai inklusif dalam hubungannya dengan perbedaan paham keagamaan pada internal Islam dan perbedaan doktrin dan sikap mental pada eksternal kelompok keagamaan merupakan refleksi dari doktrin dan sikap mental NU.

\section{NU Online: Diagnosis Narasi Kontra Radikalisasi}

Strategi diagnosis kontra radikalisasi yang dilakukan oleh NU Online menekan kajiannya pada bahaya jika narasi radikalisasi diproduksi dan didiseminasi secara intensif di dunia maya tanpa ada narasi tandingan. Bahaya tersebut tidak hanya bagi keutuhan bangsa dan negara, tetapi juga bagi agama. Sikap anti NKRI dan Pancasila sebagai ideologi negara yang diperlihatkan oleh kelompok-kelompok radikal merupakan bentuk ancaman terhadap negara. Sikap-sikap anti keragaman agama dan etnik yang mengemuka dalam bentuk 
tindakan intoleran yang menjadi karakter kelompok-kelompok radikal juga merupakan bahaya bagi nagara yang terbangun dari keragaman agama. Karena pada prinsipnya agama memiliki misi kedamaian yang ditampilkan dalam sikap inklusif dan toleran. Terkait dengan hal ini, diagnosis pencegahan radikalisasi terjadi dalam dua bentuk, yakni diagnosis bidang politik kenegaraan dan diagnosis pencegahan intoleran.

Terkait dengan diagnosis politik kenegaraan, dalam headline beritanya yang diterbitkan pada tanggal 5 November 2017, NU Online menurunkan berita dengan judul, "Radikalisme dan Intoleran jadi Sumber Kegaduhan Ideologi Negara". Headline ini mengangkatkan tausiah kebangsaan yang disampaikan oleh KH. Ma'ruf selaku Rais Am PBNU pada kegiatan "Pra Musyawarah Nasional Alim Ulama dan Konferensi Besar Nahdlatul Ulama di Pondok Pesantren al-Hikmah Bandar Lampung pada tanggal 4 November 2017. Dalam taushiyahnya Kyai Ma'ruf menilai kegaduhan bangsa saat ini terjadi dalam bentuk adanya usaha mempermasalahkan ideologi negara yang sudah ada dan mapan oleh kelompok radikal dan intoleran yang sangat berkeinginan merubah negara dengan cara kekerasan. Lebih lanjut headline ini mengungkap sikap radikal dan intoleran yang diperlihatkan oleh kelompok radikal adalah sikap yang tidak mentolerir kelompok lain yang tidak sama dengan kelompok mereka (Editor, 2017c). Headline ini menekan perhatiannya pada bahaya kehadiran kelompok radikal terhadap eksistensi negara melalui sikap mereka yang anti Pancasila dan keinginan mereka mendirikan negara dengan sistem Islam. Juga ancaman bagi agama melalui penguatan sikap eksklusif sebagai sumber dari sikap yang intoleran. Kelompok radikal menganggap paham keagamaan yang benar dan mesti menjadi rujukan dalam bersikap adalah paham keagamaan kelompok mereka (radikal). Sikap eksklusif ini bersumber dari ideologi keagamaan yang mereka miliki di mana paham keagamaan yang dimiliki dianggap lebih baik, karenanya mesti diperjuangkan sehingga bisa dijadikan patokan dalam berperilaku, termasuk perilaku berbangsa dan bernegara. Dalam politik kenegaraan, kelompok radikal memiliki ideologi bahwa sistem negara bangsa yang menganut sistem demokrasi tidak sesuai dengan sistem Islam. Karenanya untuk mewujudkan keselamatan di muka bumi, sistem negara dalam bentuk negara Islam mesti diperjuangkan.

Dalam headline yang diturunkan pada tanggal 26 Mei 2017 dengan judul berita "Bahaya Radikalisme Agama terhadap Ketahanan Pancasila", NU Online menegaskan pembelaannya terhadap keutuhan bangsa melalui narasi bahwa radikalisme merupakan ancaman yang sangat berbahaya terhadap ideologi 
negara, yakni Pancasila. Dalam narasinya NU Online menekankan diksinya pada kata-kata dan ungkapan tertentu. Di antara ungkapan tersebut adalah "Pancasila diciptakan sebagai ideologi negara yang kuat", "Pancasila merupakan sesuatu yang jelas, pokok dan sakral". Terkait dengan diksi yang pertama, NU Online hendak menekan narasi beritanya pada bahaya kelompok radikal terhadap ideologi negara. Kekuatan ideologi bangsa akan berpengaruh kepada rumah kebangsaan yang bernama Indonesia. Kekuatan rumah kebangsaan akan menjadi modal bagi bangsa ini dalam melindungi segenap bangsa Indonesia dan seluruh tumpah negara Indonesia. Sementara pada diksi yang kedua, NU Online hendak menyampaikan bahwa pembangunan negara dan peradaban tanpa didasari dengan semangat transendental (ketuhanan) dan prinsip ruhiyah yang kuat adalah ibarat membangun istana yang rapuh. Dua diksi di atas diperkuat dengan diksi terakhir, yakni Pancasila yang pokok dan sakral tersebut tidak bisa diubah dengan kondisi apa pun. "Mengganti dasar negara dengan dasar yang lain sama saja dengan menghancurkan negara". Dalam rentang 2017 sampai dengan 2019, NU Online menurunkan 10 headline berita dengan narasi terkait dengan bahaya radikalisme bagi kehidupan berbangsa dan beragama.

Berbeda dengan NU Online, Panjimas.com menampilkan headline berita yang berbeda. Dalam headline berita yang diturunkan pada tangal 5 Juli 2015 terlihat "Deradikalisasi Pasca Suriah, Pushami: Tujuan Buat Apa?". Dengan mengutip pendapat ketua Pusat Hak Asasi Muslim Indonesia (Pushami), Muhammad Hariadi Nasution, Panjimas.com justru mempertanyakan kinerja BNPT selama ini, termasuk DENSUS 88. Selama ini tidak ada lembaga pemerintah yang melakukan kontrol dan audit terhadap kinerja dua alat negara tersebut. Lebih lanjut, Panjimas.com mengutip pernyataan ketua Pushami, yang mempertanyaan keberadaan BNPT dengan ungkapan, BNPT itu dibentuk untuk apa sih, tujuannya untuk apa? Program itu dari mana? Pernah tidak BNPT dipanggil DPR terkait kinerjanya? Pengertian radikal itu dalam kamus besar Bahasa Indonesia artinya mendalam, kalau deradikalisasi dilakukan untuk melarang terwujudnya Islam kaffah, jangan-jangan nanti ada sikap yang muncul bahwa Islam yang dilakukan secara mendalam ini salah. Kemudian penanganan kasus terorisme di Indonesia hanya menyasar umat Islam. Buktinya, kasus pelaku bom Alam Sutra, Leopard Wisnu Kumala (29), tidak pernah disebut sebagai teroris sebab pelakunya beragama Katolik, ini merupakan bentuk diskriminasi. Lebih lanjut Panjimas.com dalam diksi di akhir headline beritanya menutup paragraf tersebut dengan pernyataan 
Ombat, panggilan Muhammad Hariadi, yakni daripada sekedar mengurusi orang yang memberikan bantuan dan aksi sosial usai dari Suriah, lebih baik serius menangani permasalahan komunisme. Seharusnya komunislah yang harus disasar oleh program deradikalisasi (Editor, 2017a).

Selain mengembangkan narasi bahaya radikalisme bagi keutuhan negara, NU Online juga giat mengembangkan narasi bahwa radikalisme merupakan ancaman bagi toleransi dalam keragaman, baik etnisitas maupun agama. "Truth claim" yang dimiliki oleh kelompok-kelompok radikal membawanya kepada sikap mental eksklusif dengan model apologi keagamaan antitesis, yakni menganggap paham keagamaan dan kelompoknya yang paling benar, sementara paham dan kelompok keagamaan yang lain dianggap salah (Hendro Puspito, 1993). Lebih berbahaya dan merupakan potensi konflik adalah kemestian menjadikan paham keagamaan yang dimiliki dan kelompok sosial yang dipunyai menjadi rujukan bagi kelompok lain yang berbeda dengan mereka. Sikap ini memunculkan sikap beragama rendahan seperti memandang amalan yang dilakukan oleh kelompok keagamaan lain penuh dengan bid'ah dan mereka yang melakukannya dianggap kafir, karena tidak berislam dengan Islam yang benar. Sikap eksklusif kelompok-kelompok radikal ini tidak hanya ditujukan kepada eksternal Islam, tetapi juga pada internal Islam. Dalam headline sebelumnya, NU online merilis pernyataan K.H. Ma'ruf Amien, yakni kelompok radikal menganggap hanya cara beragama kelompoknya saja yang benar. Jangankan dengan non-muslim, sesama Muslim saja mereka labeli dengan diksi-diksi seperti sesat dan bahkan kafir. Karenanya kelompok ini dinamakan takfiri. Label yang diberikan seiring dengan sikap mental beragama mereka yang suka mengkafirkan orang lain.

\section{NU Online: Prognosis Kontra Radikalisasi}

Jika strategi diagnosis menekankan perhatiannya pada sebab-sebab kesalahan dari sebuah gagasan atau peristiwa yang dinarasikan. Strategi prognosis berperan menindaklanjuti diagnosis yang telah diambil dalam bentuk pemberian solusi atau obat. Karenanya narasi dan konten yang diproduksi dan didiseminasi adalah narasi dan konten moderat dan toleran. Kalau pada penjelasan sebelumnya, NU Online mendiagnosis bahwa radikalisasi sangat berpotensi membawa kegaduhan dan bahkan merusak ideologi bangsa dan melahirkan sikap intoleran dalam bentuk kekerasan, strategi prognosisnya adalah mengembangkan sikap-sikap moderat dan toleran. 
Sama halnya dengan strategi diagnosis, produksi dan diseminasi konten dan narasi yang lebih banyak ditelaah dalam strategi prognosis adalah konten dan narasi yang berisi pembelaan terhadap ideologi negara dari ancaman kelompok radikal. Jika situs-situs kelompok radikal memproduksi dan mendiseminasi konten dan narasi politik terkait dengan kemestian adanya negara Islam atau penerapan syariat Islam dalam negara untuk mewujudkan berlakunya hukum Islam, strategi prognosis berusaha memproduksi dan mendiseminasi konten dan narasi bahwa ide pendirian negara Islam dalam bentuk khilafah merupakan ancaman terhadap Pancaasila dan NKRI. Kalau kelompok-kelompok radikal memproduksi dan mendiseminasi konten dan narasi eksklusif, strategi prognosis melakukan hal yang sebaliknya, yakni memproduksi dan mendiseminasi narasi seperti sikap eksklusif merupakan ancaman bagi negara yang terbangun dari keragaman agama dan etnik seperti Indonesia.

Terkait dengan hal ini maka diksi-diksi yang diproduksi dan didiseminasi oleh NU Online sebagaimana terlihat dalam Headline-headline berita yang diturunkannya adalah "Gagal Paham soal Khilafah", "Empat Alasan Kenapa Khilafah Ditolak", "Memahami Konsep Khilafah dari Mata Air Jernih", "Khilafah Produksi Sejarah, Bukan Syariah", "Beda Khalifah dan Khilafah". Diksi-diksi pada headline-headline berita ini berusaha memproduksi dan mendiseminasi konten dan narasi moderasi sebagai bentuk kontra radikalisasi politik dari radikalisasi politik yang dilakukan oleh kelompok radikal yang menghendaki berdirinya khilafah sebagai alternatif dari NKRI dan keinginan mereka menggantikan ideologi negara dengan ideologi agama atau pendirian negara dengan sistem Islam sebagai alternatif kesemrawutan demokrasi.

Pada headline berita yang diturunkan pada tanggal 31 Maret 2019 dengan judul berita "Gagal Paham Soal Khilafah", pada awal paragraf beritanya NU Online memilih diksi "Kesalahpahaman dalam menerjemahkan bentuk negara Islam bagi mereka yang gigih memperjuangkan khilafah". Dalam headline berita ini, NU Online memberikan narasi yang lebih kontekstual yang berbeda dengan pemahaman tekstual yang dimiliki oleh kelompok Islam pengusung Khilafah. Bagi NU Online, konten hadis nabi yang berbunyi "khilafah 'ala minhajin nubuwwah" tidak dapat diartikan secara literal atau apa adanya, yakni akan muncul khilafah yang sesuai dengan manhaj kenabian. Akan tetapi, khilafah di sini lebih tepat dimaknai dengan salah satu bentuk negara yang pernah dipraktikkan oleh umat Islam, baik berbentuk 
imamah, imarah, maupun mamlakah (kerajaan) dan Syura (republik). Karenanya makna khilafah bukan hanya dimaknai dalam bentuk mendirikan negara Islam atau "daulah Islamiyah". Ia lebih tepat dipahami dalam arti sistem pemerintahan. Jika sebuah sistem pemerintahan tersebut dapat membawa rakyat pada kondisi aman, adil, makmur, dan sejahtera, maka apa pun bentuk sistem pemerintahannya sudah termasuk "khilafah 'ala minhajin nubuwwah". Begitu juga dengan khilafah yang terus diperjuangkan oleh Hizbut Tahrir. Dalam konteks Negara Kesatuan Republik Indonesia (NKRI), kelompok Hizbut Tahrir ingin mengubah dasar negara dengan menolak Pancasila dan segala sistemnya. Dengan berpedoman kepada Piagam Madinah, NU Online menegaskan bahwa Pancasila merupakan konsensus kebangsaan yang disepakati oleh para pendiri bangsa (founding fathers) Indonesia. Para pendiri bangsa di antaranya terdiri dari para ulama dan aktivis Islam. Mereka paham agama dan fiqh siyasah sehingga negara berdasarkan Pancasila tidak menyalahi syariat Islam. Justru syariat dan nilai-nilai Islam menjadi jiwa bagi Pancasila. Ketuhanan, kemanusiaan, persatuan, musyawarah, dan keadilan sosial merupakan nilai-nilai universal Islam yang terkandung dalam Pancasila (Editor, 2019b).

Dalam headline beritanya yang diturunkan pada tanggal 1 Desember 2017 dengan judul berita "Teriak NKRI Harga Mati Harus Punya Dasar", NU Online menguatkan narasi pencegahan radikalisasi dengan mengutip pendapat Maulana Habib Luthfi. Bagi Habib, meneriakkan NKRI harga mati mesti punya dasar. Habib Luthfi mengatakan, sekarang ini kita menghadapi berbagai macam gempuran dari luar, mulai dari berita-berita hoaks yang begitu banyak tersebar di media, yang mengancam stabilitas dan kenyamanan masyarakat sampai pada sesuatu yang mengancam ideologi negara. Habib mengingatkan bahwa hoaks dan provokasi sudah ada sejak zaman dahulu. Kalau dihubungkan dengan yang terjadi sekarang, hal itu sama polanya dengan yang terjadi pada zaman dahulu. Peristiwa tahkim di zaman sahabat Ali Bin Abu Tholib, hingga runtuhnya kerajaan-kerajaan besar yang ada di Indonesia maupun di dunia, hal itu banyak terjadi karena hoaks dan pembusukan dari dalam. Berdasarkan hal di atas maka, teriak NKRI harga mati bukan teriak asal-asalan. Teriaknya didasarkan pada sejarah yang pernah terjadi pada masa silam agar tidak terjadi lagi pada masa sekarang (Editor, 2017d).

Pada headline sebelumnya dengan judul berita "Ini Alasan NKRI Harga Mati bagi NU", NU Online mengutip pendapat KH. Ahmad Azhar Shofwan, ketua PW Lembaga Bahtsul Masail NU Jawa Timur terkait alasan fundamental 
menjadikan NKRI sebagai pilihan yang mutlak bagi NU. Kyai Azhar menjelaskan, setidaknya ada tiga alasan terkait hal ini: pertama, bagi NU, negara bukanlah sebagai tujuan, selama negara bisa menjamin terlindunginya lima hal pokok atau "ushulul khams", maka sudah seharusnya keberadaannya didukung. Kelima hal pokok tersebut adalah terjaganya akal, agama, harta, keturunan serta jiwa atau nyawa. Kedua, secara substantif keberadaan NKRI sudah sesuai dengan syariat. Karena dalam praktiknya, masyarakat muslim atau warga negara bisa menjalankan syariat Islam secara penuh. Kyai Azhar merinci bahwa selama ini banyak undang-undang atau peraturan di negara Indonesia yang bisa mengakomodasi pelaksanaan syariat Islam. Seperti berlakunya undang-undang perkawinan, waris, zakat, juga pengelolaan fakir miskin. Bahkan untuk yang terakhir ini, yakni penanganan fakir miskin di tanah air sudah sesuai dengan tatanan yang disyariatkan dalam Islam. Ketiga, NU menyadari akan kebhinekaan bangsa Indonesia, karenanya menghadapi keberagaman itu harus dengan sikap yang arif agar kemajemukan yang ada tetap bisa terjaga dengan baik. Karenanya, NKRI menjadi upaya membenarkan rasa aman dan damai, tanpa harus ada pihak yang dicederai (Editor, 2015b).

Untuk menepis bahaya radikalisasi politik, NU Online juga menurunkan headline berita seperti "Menpora: Tangkal Radikalisme dengan semangat Nasionalisme". Headline berita yang diturunkan pada tanggal 17 November 2017 ini mengungkap pendapat Menteri Pemuda dan Olah Raga ketika memberikan orasi ilmiah pada acara seminar nasional dengan tema "Meningkatkan Nasionalisme terhadap Pengaruh Paham Radikalisme" di Covention Center Sekolah Tinggi Ilmu Ekonomi (STIE) Sumbar Pariaman. Bagi Menteri sebagaimana dikutip oleh NU Online, nasionalisme dengan kebhinekaan dan NKRI sebagai pilarnya tidak akan pernah goyah manakala semua warga negara menyalurkan virus positif. Rasa nasionalisme merupakan rasa cinta dan rasa memiliki bangsa sendiri. Rasa ini timbul apabila kita benarbenar menghayati pentingnya peran kita sebagai fondasi bangsa. Fondasi bangsa yang kuat bisa menopang bangsa dari guncangan yang terjadi akibat pengaruh-pengaruh yang ditimbulkan oleh orang-orang yang tidak bertanggung jawab dan berpikir sempit yang tidak ingin merasakan persatuan dan keharmonisan bangsa Indonesia, apalagi ingin memisahkan diri dari Indonesia (Editor, 2017b).

Berbeda dengan headline NU Onlien, Panjimas.com menurunkan headlinenya, "Sinergitas Alim Ulama, Habaib dan Cendekiawan Muslim Munuju NKRI Bersyariah". Pada awal paragraf beritanya, Panjimas.com 
menekankan apresiasinya terhadap hasil Muzakarah Alim Ulama, Habaib dan Cendekiawan Muslim yang telah berhasil membentuk Majelis Tinggi DKI Jakarta Besyariah. Bagi Panjimas.com, muzakarah yang dihadiri oleh para tokoh di Jakarta yang ketokohan, ilmu agama dan ilmu umumnya tidak diragukan lagi merupakan forum penyangga keumatan. Majelis Tinggi ini sesuai dengan namanya berjuang secara konstitusional untuk menerapkan nilai-nilai syariat Islam dalam kehidupan berbangsa dan bernegara. Dalam paragraf awal berita ini juga ditekan bahwa perjuangan menerapkan syariat Islam, baik secara formal maupun substansial dalam sistem politik hukum, tentu bukan pekerjaan yang mudah. Rintangan selalu hadir, sikap kontra dari kalangan SEPILIS (sekularisme, pluralisme dan liberalisme), dipastikan akan selalu ada, namun di situlah letak dan makna suatu perjuangan.

Dalam menopang perjuangan penerapan syariat Islam ini, pada paragraf keempat dari berita ini, Panjimas.com melegitimasi arah perjuangannya dengan mengutip pendapat tokoh-tokoh Islam seperti al-Mawardi, seorang teoritikus politik Islam dan Imam al-Gazali. Dalam kitabnya "al-Ahkam al Sulthaniyah, al-Mawardi menegaskan bahwa kepemimpinan negara merupakan instrumen untuk meneruskan misi kenabian guna memelihara agama dan mengatur dunia. Pemeliharaan agama dan pengaturan dunia merupakan dua aktivitas yang berbeda, tetapi berhubungan secara simbiotik. Keduanya merupakan dua dimensi dari misi kenabian. Imam al-Ghazali juga dikategorikan sebagai pemikir yang membawa pandangan simbiotik antara agama dan negara. Meskipun Imam al-Ghazali tidak secara khusus dikenal sebagai pemikir politik, namun beberapa karyanya memiliki muatan politik yang cukup signifikan, seperti "Nasiat al-Mulk", "Kimiyawi al-Sa'adahdan "al-Iqtishad ji al-I'tiqad". Dalam "Nasihat al-Mulk", ia mengisyaratkan hubungan antara agama dan negara, yakni tentang paralelisme raja dan Nabi. Menurutnya sebagaimana dikutip oleh Panjumas.com, Tuhan telah mengirim nabi-nabi dan memberikan kekuatan Ilahi kepada mereka, yang tujuannya adalah memberikan kemaslahatan bagi umat manusia.

Lebih lanjut, Panjimas.com menjelaskan, dalam konteks ini, ia tidak bermaksud menyamakan nabi dengan raja. Namun paralelisme yang dilakukannya menunjukkan bahwa raja atau agama memiliki hubungan yang kaut dengan negara. Bahkan, ia berpendapat bahwa agama dan negara adalah saudara kembar yang lahir dari satu ibu. Begitu dekatnya hubungan agama dan negara, sampai-sampai ia mengatakan "agama adalah dasar dan sultan adalah penjaganya." Di akhir paragrafnya, Panjimas.com menutup beritanya dengan 
kewajiban umat Islam memberikan dukungan terhadap "Majelis Tinggi DKI Bersyariah" dengan penuh keyakinan dan keikhlasan dan sangat berharap kepemimpinan nasional juga mampu mempertemukan agama dan negara dalam kepentingan tujuan dan cita-cita nasional (Editor, 2015c).

\section{NU Online: Motivasional Kontra Radikalisasi}

Ajakan pembelaan terhadap Pancasila dan NKRI, serta kebhinekaan sebagaimana terlihat dalam headline berita NU Online merupakan bentuk dari pembingkaian motivasional yang dilakukan oleh media online milik organisasi Islam arus utama ini terhadap keutuhan negara. Dalam headline beritanya yang diturunkan pada tanggal 1 Juni 2018, NU Online mempertegas komitmen NU sebagai pembela dan pemelihara Pancasila. Melalui headline beritanya, "NU sebagai Benteng Pancasila", media online ini membuka paragrafnya dengan diksi "Indonesia tak henti-hentinya diterpa badai problematika kebangsaan. Selain korupsi dan terorisme, adanya kelompok yang berusaha melakukan delegitimasi terhadap Pancasila sebagai Asas Tunggal dan ideologi negara juga merupakan persoalan yang masih belum selesai. Islam transnasional menjadi motor gerakan ini dengan dalih agama".

Terhadap tantangan di atas, NU sebagaimana diungkap oleh NU Online telah melakukan usaha-usaha penguatan ideologi negara. Pada Musyawarah Nasional (Munas) Alim Ulama Nahdlatul Ulama di Situbondo tahun 1983 telah menetapkan penerimaannya terhadap Pancasila sebagai Asas Tunggal. Dengan mengutip pendapat Einar Martahan Sitompul dalam bukunya "NU dan Pancasila", NU Online mengungkap tiga alasan mudahnya peserta Munas menerima Asas Tunggal, yakni: Pertama, para Kyai yang mengemukakan pendapatnya adalah para Kyai khos, yakni KH As'ad Syamsul Arifin, KH Ali Ma'sum, KH Mharus Ali, KH Ahmad Shiddiq, dan KH Masykur. Mereka ini mempunyai wibawa yang kuat di mata umat sehingga segan menolak pandangannya. Kedua, keputusan para Kyai sepuh tersebut pasti sudah dipikirkan dengan sangat matang, tidak semata pertimbangan politis. Faktor keagamaan pun pasti tak lepas dari ketepatan yang telah mereka ambil. Ketiga, sebagai pemimpin umat mereka peka terhadap perkembangan dan keutuhan umat.

Musyawarah Nasional Alim Ulama NU pada tahun 1983 di Pondok Pesantren Syafi'yah Situbondo, Jawa Timur menegaskan sikap NU terhadap Asas Tunggal, yakni: pertama, Pancasila sebagai dasar dan falsafah Negara Republik Indonesia bukanlah agama, dan tidak dapat menggantikan agama, dan tidak dapat digunakan untuk menggantikan kedudukan agama. Kedua, sila Ketuhanan Yang Maha Esa sebagai dasar Negara Republik Indonesia, menurut 
pasal 29 ayat (1) undang-undang dasar 1945, yang menjiwai sila-sila yang lain mencerminkan tauhid menurut pengertian keimanan dalam Islam. Ketiga, bagi Nahdlatul Ulama, Islam adalah akidah dan syariah, meliputi aspek hubungan manusia dengan Allah dan hubungan manusia antar manusia. Keempat, penerimaan dan pengamalan Pancasila merupakan wujud dari upaya umat Islam Indonesia untuk menjalankan syariat agamanya. Kelima, sebagai konsekuensi dari sikap itu, Nahdlatul Ulama berkewajiban mengamankan pengertian yang benar asli dan pengamalannya yang murni dan konsekuen oleh semua pihak.

Dalam pembelaannya terhadap ideologi negara, NU Online menurunkan headline beritanya seperti "Gagal Paham Soal Khilafah", Khilafah dalam Pandangan NU", "Menengok Kembali Makna Khilafah dan Khalifah", "Empat Alasan Kenapa Khalifah Ditolak", "Memahami Konsep Khilafah dari Mata Air Jernih", "Khilafah Produk Sejarah, Bukan Syariah", "Beda Khalifah dan Khilafah", "Kiai Muchith: NU Tolak Khilafah Islamiyah atas Dasar yang Jelas". Semua headline ini menguatkan keberadaan NKRI melalui nilai-nilai keislaman. Kehadiran Islam tidak bertentangan dengan negara, melainkan mengukuhkan negara.

\section{Simpulan}

Pesatnya pertumbuhan situs-situs radikal di dunia maya memiliki dampak buruk bagi keutuhan bangsa dan agama. Produksi dan diseminasi narasi anti Pancasila dan NKRI di dunia maya berdampak buruk bagi ketahanan sendi-sendi kehidupan berbangsa dan bernegara. Sikap eksklusif dalam keragaman agama dan paham keagamaan merupakan sumber dari sikap intoleran yang juga sangat potensial bagi konflik sosial keagamaan. NU Online mendiagnosis bahwa produksi dan diseminasi narasi radikalisasi di dunia maya sangat berbahaya bagi keutuhan bangsa dan agama. Radikalisme dan intoleran merupakan sumber kegaduhan ideologi bangsa. NU Online mengajak seluruh elemen bangsa untuk memelihara sikap moderat dan toleran, terutama dalam kaitannya dengan usaha-usaha menjaga keutuhan bangsa dan agama. Dalam headline-headline yang diturunkannya, NU Online tidak luput memberikan penjelasan kepada konsumennya untuk terhindar dari bahaya radikalisasi. Ajakan-ajakan untuk terhindar dari bahaya radikalisme sebagai bagian dari strategi motivasional yang dilakukan oleh NU Online terlihat dalam bentuk seruan yang bersifat mengingatkan bahwa ada usaha-usaha mendelegitimasi Pancasila sebagai Asas Tunggal dan Ideologi negara oleh gerakan Islam transnasional dengan dalih agama. 


\section{Referensi}

Abdul Muchith Muzadi. (2010). Mengenal Dahdatul Ulama. Khalista.

Ade Armando at.al. (2011). Media dan Integrasi Sosial: Jembatan Antar Umat Beragama (Irfan Abubakar dan Muchtadlirin (ed.); 1 ed.). CSRC UIN Jakarta.

Afrizal. (2014). Metode Penelitian Kualitatif: Sebuah Upaya Mendukung Penggunaan Penelitian Kualittif dalam Berbagai Disiplin Ilmu (1 ed.). Rajawali Press.

Akil N. Awan. (2015). Virtual Jihadist Media: Function, legitimacy and radicalizing efficacy.

Amelia Fauzia at.al. (2011). Islam di Ruang Publik: Politik Identitas dan Masa Depan Demokrasi di Indonesia (N. Hasan \& Irfan Abubakar (ed.); pertama). CSRC UIN Jakarta.

Benford, R. D., Snow, D. A., Benford, R. D., \& Snow, D. A. (2012). FRAMING PROCESSES AND SOCIAL MOVEMENTS : An Overview and Assessment. 26(2000), 611-639.

editor. (2019). Mempromosikan Persatuan Melalui Dunia Maya juga Termasuk Jihad. NU.or.id.

Editor. (2015a). BNPT Minta Kominfo Blokir 22 Situs Radikal. Kominfo.

Editor. (2015b). Ini Alasan NKRI Harga Mati bagi NU. NU.or.id.

Editor. (2015c). Sinergitas Alim Ulama, Habib, dan Cendikiawan Muslim Menuju NKRI Bersyariah. Panjimas.com.

Editor. (2017a). Deradikalisasi Pasca dari Suriah Pushami Tujuannya Buat Apa? Panjimas.com.

Editor. (2017b). Menpora: Tangkal Radikalisme dengan Semangat Nasionalisme. NU.or.id.

Editor. (2017c). Radikalisme dan Intoleran jadi Sumber Kegaduhan Ideologi Negara. nu.or,id.

Editor. (2017d). Teriak NKRI Harga Mati Harus Punya Dasar. Nu.or.id.

Editor. (2018a). 40 \% Milenial Muslim Indonesia Berorientasi Nasionalis-Religius. Tirto.id.

Editor. (2018b). BIN: 41 Masjid di Kementerian-Lembaga-BUMN Terpapar Paham Radikal. Detik.com.

Editor. (2018c). BIN Benarkan 39 Persen Mahasiswa di 7 PTN Terpapar Radikalisme. Liputan6com.

Editor. (2018d). Dedi Mulyadi Usulkan Pemecatan PNS Anti Pancasila. Kompas.

Editor. (2018e). Dominasi Situs-Situs Radikal. Tempo.co.

Editor. (2018f). Kemendagri Sebut 19,4 Persen PNS Tak Setuju Ideologi Pancasila. Tirto.id.

Editor. (2018g). Kominfo Sudah Blokir 814.594 Situs Radikal. Kominfo.

Editor. (2019a). Berapa Pengguna Media Sosial di Indonesia. Databoks.

Editor. (2019b). Gagal Paham Soal Khilafah. NU.or.id. 
Editor. (2019c). Selama 10 Tahun Terakhir Kominfo Blokir Lebih dari 11.ooo Konten Radikalisme-Terorisme. Kominfo.

Eriyanto. (2012). Analisis Framing (D. Mulyana (ed.); ketiga). LKiS.

Fatoni, M. S. (2017). Buku Pintar Islam Nusantara. Pustaka Iman.

Jamil, A. (n.d.). Gerakan Sosial dalam Perspektif Framing: Studi Pembentukan Proses dan Pertarungan Framing pada Gerakan Sosial Sengketa Komisi Pemberantasan Korupsi KPK dengan Polri 2009 dan 2012. Lib.ui.ac.id.

Jean-Pierre Filliu. (2014). The Local and Global Jihad of al-Qa ' ida in the Islamic Maghrib. 63(2), 213-226.

John W. Creswell. (2015). Penelitian Kualitatif \& Desain Riset: Memilih di antara Lima Pendekatan (Saifuddin Zuhri Qudsy (ed.); 3 ed.). Pustaka Pelajar.

Kuswarno, E. (2015). Potret Wajah Masyarakat Digital Indonesia. COMMUNICATE, 1(1).

Said Ali, A. (2002). Al-Qaeda Tinjauan Sosial-Politik, Ideologi dan Sepak Terjangnya (N. I. Abdullah (ed.); kedua). LP3ES.

Setiadi, E. M., \& Kolip, U. (2010). Pengantar Sosiologi: Pemahaman Fakta dan Gejala Permasalahan Sosial, Teori, Aplikasi, dan Pemecahannya (1 ed.). Predana Media Group.

Soekanto, S. (2017). Sosiologi Suatu Pengantar (48 ed.). Rajawali Press.

Umar, N. (2019). Islam Nusantara: Jalan Panjang Moderasi Beragama di Indonesia (J. Zarkasy (ed.)). Elex Media Komputindo.

Wiktorowicz, Q. (2007). Introduction: Islamic Activism and Social Movement Theory. In Q. Wiktorowicz (Ed.), Islamic Activisme: A Social Movement Theory Approach (1 ed., hal. 316). Indiana University Press. 
This page intentionally left blank 